\title{
Basal defoliation and their influence in agronomic and phytopathological traits in tomato plants
}

\author{
Laércio J da Silva; Carla do C Milagres; Derly José H da Silva; Carlos Nick; João Paulo A de Castro \\ ${ }^{1}$ UFV, 36570-000 Viçosa-MG; laercio.silva@ufv.br
}

\begin{abstract}
The incidence of leaf diseases is one of the main factors limiting the tomato crop production, increasing the production cost due to excessive pesticide application. The basal leaf removal could reduce inoculum sources, disease severity and contribute to reducing the use of pesticide. Aiming to evaluate the efficiency of this practice on the reduction of tomato leaf diseases and the effect in the quality and in the productivity of the tomato plants for in natura consumption, two experiments were carried out to test four levels of basal leaf removal. Basal leaves removal, at fruit harvesting, is efficient in reducing the infected plant area by disease, what can mean smaller disease severity and least inoculum source in the field. Also, the all basal leaf removal does not affect yield and quality of the tomato fruits. Other studies are necessary to evaluate the effect of adopting this practice in different planting dates, spacing, varieties, successive plantings and the financial viability of adopting this practice.
\end{abstract}

Keywords: Lycopersicon esculentum, defoliation, plant disease, cultural management.

\begin{abstract}
RESUMO
Desfolha baixeira e sua influência em caracteres fitotécnicos e fitopatológicos do tomateiro

A incidência de doenças foliares é um dos principais fatores que limitam a produção da cultura do tomate, aumentando o custo de produção pela necessária aplicação de defensivos. A retirada de folhas baixeiras poderia contribuir para a redução de fontes de inóculo e redução da severidade de doenças, reduzindo dessa forma a necessidade de aplicação de agrotóxicos. Com o objetivo de avaliar a eficiência dessa prática na redução de doenças foliares do tomateiro e o efeito na qualidade e na produtividade total e comercial de cultivares utilizadas para consumo in natura, foram instalados dois experimentos, sendo testados quatro níveis de retirada de folhas baixeiras. Foi observado que a retirada das folhas baixeiras, à medida que é feita a colheita dos frutos, é eficiente para reduzir a área foliar lesionada por doenças, o que pode significar menor severidade e diminuição de inóculo na área de cultivo. A retirada dessas folhas não interfere na produtividade e qualidade de frutos de tomateiro. Outros estudos precisam ser feitos para avaliar o efeito da adoção dessa prática em diferentes épocas de plantio, espaçamentos, variedades, cultivos sucessivos, bem como a viabilidade financeira de sua utilização.
\end{abstract}

Palavras-chave: Lycopersicon esculentum, desfolha, doenças de plantas, manejo cultural.

(Recebido para publicação em 19 de novembro de 2009; aceito em 3 de março de 2011)

(Received on November 19, 2009; accepted on March 3, 2011)

$\mathrm{T}^{\mathrm{s}}$ omatoes are susceptible to many diseases and this is one of the crop's principal limiting factors (Vale et al, 2007). Excessive application of agricultural chemicals to control diseases and pests is a common practice and results in problems related to environmental contamination, the applicators, consumers and the producers themselves (Barreto \& Scaloppi, 2000; Nakano, 1999).

In Minas Gerais, the main leaf diseases in tomatoes are late blight (Phytophthora infestans) and early blight (Alternaria solani) and 18 to 20 applications normally are performed during the crop cycle to control these diseases (Salustiano et al., 2006). In the tomato crop, in 2008 around
$4 \%$ of the production costs were spent on fungicides and represented approximately $69 \%$ of expenses with agricultural chemicals (Agrianual, 2009).

Late blight is the most destructive disease in the tomato crop. It is disseminated by wind and rain carried spores and needs free water to germinate (Lopes \& Ávila, 2005; Vale et al., 2007). According to these authors the first symptoms appear on the upper half of the plants, but the oomycete occur throughout the canopy, causing tissue death and leaf loss. A tomato variety has not yet been developed with durable resistance to this pathogen, so this disease is almost exclusively controlled with fungicide application (Mizubuti,
2001).

The fungus that causes early blight is disseminated by the wind and also by the seeds (Lopes \& Ávila, 2005). The fungus occurs mainly on the older leaves and causes circular dark brown spots with concentric rings due to the irregular growth of the fungus on the plant tissues and in severe attacks the older leaves dry out (Lopes \& Ávila, 2005; Vale et al., 2007). In varieties without resistance to this pathogen, it is controlled basically by applying chemical products (Vale et al., 2000).

Other diseases that are also economically important and contribute to reduced tomato yield are septoria leaf spot (Septoria lycopersici) and gray leaf spot (Stemphylium solani). Septoria leaf 
spot can be confused with early blight because the symptoms are similar when the lesions are not yet fully developed (Lopes \& Ávila, 2005). The symptoms of this disease appear mainly on the basal leaves (Vale et al., 2007).

Gray leaf spot occurs mainly on younger leaves and causes losses because of the reduction in the leaf photosynthesis activity. It is of increasing importance because of its greater occurrence in geminivirus-resistant tomato hybrids (Vale et al., 2007).

Crop treatments and the how the crop is conducted are very important for the management of these diseases and to obtain good quality fruit, always with the object of decreasing production costs, especially with fewer chemical applications.

In this context, removing the infected leaves together with chemical control has been used as a control tactic for some tomato diseases but it is not a usual practice in Brazil (Blume \& Jara, 2004; Guimarães et al, 2007).

Due to the decrease in the infestation and the modification in the microclimate, making it less favorable to disease proliferation, removing the basal leaves of the plant could be used as an auxiliary control measure. When these leaves are removed, aeration is increased and moisture decreases, making the environment less propitious to disease development.

Usually basal leaves are removed when they present nutritional deficiencies or when they are senescent, but there is no information on the viability of this technique in reducing leaf diseases and especially its effect on tomato yield and fruit quality (Guimarães et al., 2007).

Thus the objectives of the present study were to verify the viability and efficiency of removing the basal leaves in decreasing leaf disease severity and its effect on tomato yield and fruit for in natura consumption.

\section{MATERIAL AND METHODS}

Two experiments were set up in different periods. The first was carried out from $18 / 05$ to $11 / 12 / 2007$ and the second from $20 / 08 / 2008$ to $08 / 01 / 2009$, both in the Olericulture Sector of the Plant Pathology of the Federal University of Viçosa. The 'Alambra' cultivar was used in the first experiment and the 'Alambra' and 'Paron' hyrbids in the second experiment. The seedlings were produced in a greenhouse on extruded polystyrene trays with commercial substrate for seedling production. They were transplanted 32 days after sowing in the first experiment, and 36 days after sowing in the second experiment. They were fertilized according to soil analysis, individually for each sub-area in the second experiment, following the recommendations of the Minas Gerais Soil Fertility Commission (1999) for the tomato crop. Diseases were controlled

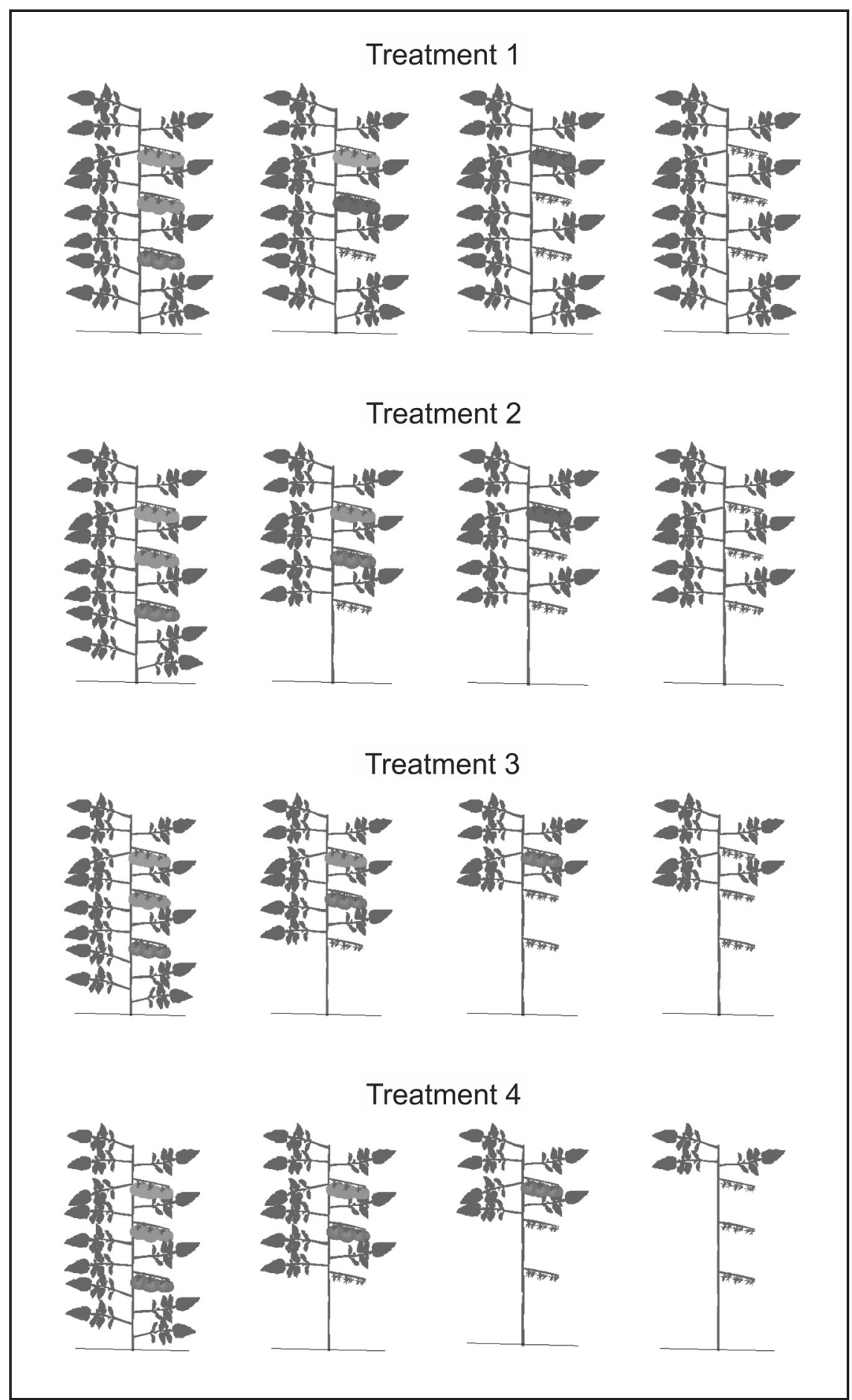

Figure 1. Schematic picture of the basal leaf removal treatments (esquema ilustrativo dos tratamentos de retirada de folhas baixeiras). Viçosa, UFV, 2009. 
whenever necessary by applying agricultural chemicals. In the first experiment there were 12 leaf sprayings and in the second 14 . The main active ingredients used in the applications were cymoxanil + mancozeb, chlorotalonyl + copper oxichloride, dimetomorph, famoxadone + mancozeb, mancozeb, mancozeb + metalaxyl-M, copper oxicloride and tebuconazole.

The between-plant spacing used was $0.6 \mathrm{~m}$ and $1 \mathrm{~m}$ between row spacing, and the plants were trained up a stake. The plants were conducted until flower emission of the $10^{\text {th }}$ inflorescence, after which the new inflorescences were removed as they appeared. In the second experiment, this procedure was adopted after the six ${ }^{\text {th }}$ inflorescence due to the high disease occurrence that made it impossible to cultivate the plants to the $10^{\text {th }}$ inflorescence.

The treatments consisted of different leaf removal levels (Figure 1): T1 without removing the basal leaves (control); T2 removing one third of the basal leaves; T3 removing two thirds of the basal leaves and $\mathrm{T} 4$ removing all the basal leaves. Leaves were considered basal leaves that were located below the third inflorescence, counted from the bottom to the top.

The leaves were removed gradually according to the harvesting of the fruit of the three first inflorescences. Thus, after the first inflorescence had been completely harvested on $80 \%$ of the plants, the leaves below this inflorescence were removed in treatments T2, T3 and T4. When the second inflorescence had been completely harvested from $80 \%$ of the plants, the leaves below this inflorescence were removed from the plant in treatments T3 and T4. When the third inflorescence had been completely harvested of $80 \%$ of the plants, the leaves below this inflorescence were removed on the T4 plants.

The leaves were always removed at the end of the afternoon, following recommendations for the bud stripping operation (Guimarães et al., 2007). The leaves were cut with a pen knife that was disinfected with a solution of sodium hypochlorite ( $2 \%$ ) before use on each plant. After all the operations, copper fungicide was applied to protect the wounds and prevent disease. After removal the leaves were taken from the experimental area and disposed of in an appropriate location.

A randomized block design was used in the first experiment with five replications. Each plot consisted of five plants and the three central plants were considered useful. The data obtained were submitted to analysis of variance and the means compared by the Tukey test $(\mathrm{p}<0.05)$.

The second experiment was set up in four sub-areas, used with a minimum distance of $100 \mathrm{~m}$ between them to isolate possible interference in the damaged leaf area of the plant in the different treatments. In each subarea a removal treatment was applied to the basal leaves. The treatments were distributed randomly among the sub-areas. The plot consisted of five plants and the three central plants were considered useful of one of the hybrids, 'Alambra' or 'Paron', that were distributed in randomized blocks within each sub-area with five replications. The obtained data were submitted to individual analysis of variance for the sub-areas. After verifying that the quotient between the minimum squares of the residues of the individual analyses were less than seven (Gomes \& Garcia, 2002), joint analyses were made of the sub-areas and the means compared by the Tukey test $(\mathrm{p}<0.05)$.

The disease severity on the plant was assessed weekly and the assessments began in the first week after transplanting and finished in the week of the last harvest. The percentage of damaged leaf area and the diseases present were assessed and the assessors had been trained previously to use the Severity PRO program (Nutter, 1997), to standardize the visual estimates of percentage of damaged leaf area.

Each block had a single assessor and each one gave a score for each leaf of each plant assessed. All the leaves of the plant were assessed in the assessments and the scores consisted of the percentage of damaged leaf area. The means were obtained from the data of damaged leaf area per plant for each plot and for each day of assessment. In order to verify the effect of the treatments on the leaf area damaged by the plant diseases, the treatments were compared at the last assessment.

The fruits were harvested weekly and separated by inflorescence when they were at the red ripe stage (Brasil, 1995). After harvesting, the fruits were classified, weighed and taken to the laboratory for later analysis of qualityrelated characteristics. The analyses consisted of determining the $\mathrm{pH}$, titratable acidity, soluble solid content, fruit diameter, mesocarp thickness and firmness.

The data were analyzed using the Statistical Analysis System SAS (SAS, 1989).

\section{RESULTS AND DISCUSSION}

The greatest disease incidence in the tomato plants of the first experiment was early blight, with less occurrence of septoria leaf spot and gray leaf spot. Late blight occurred with greater intensity in the second experiment and was one of the main reasons the plants could not be conducted to the $10^{\text {th }}$ inflorescence, as mentioned previously. Early blight was also observed and gray leaf spot in smaller proportions. In the second experiment, even though the total period when the plant remained in the field was shorter, there was a higher number of fungicide leaf applications because of the greater disease incidence (Table 1). During the execution of the second experiment, there was a total rainfall index of $1095 \mathrm{~mm}$ that was very high compared to the total of $185 \mathrm{~mm}$ in the first experiment. The temperature values were similar in both experiments. Thus high moisture was the main cause of the greater disease incidence in the plants in the second experiment.

In the first experiment, the basal leaves were removed below the first, second and third inflorescences at 109, 110 and 120 days after transplant, respectively, corresponding to the harvest of $80 \%$ of the fruits on the respective inflorescences. In the second experiment, leaves were removed, from the two cultivars, below the first, second and third inflorescences at 119, 127 and 130 days after transplant, respectively. 
Table 1. Means of the leaf area lesioned by diseases (\%) of tomato plants submitted to different levels of retreat of lower leaves (média de área foliar lesionada por doenças (\%) de plantas de tomateiro submetidas a diferentes níveis de retirada de folhas baixeiras). Viçosa, UFV, 2009.

\begin{tabular}{lcccccc}
\hline \multirow{2}{*}{ Treatment } & \multicolumn{2}{c}{ First experiment } & & \multicolumn{2}{c}{ Second experiment } \\
\cline { 2 - 3 } & $\begin{array}{c}\text { Whole } \\
\text { plant }\end{array}$ & $\begin{array}{c}\text { Above 3 } \\
\text { inflorescence }\end{array}$ & & $\begin{array}{c}\text { Whole } \\
\text { plant }\end{array}$ & $\begin{array}{c}\text { Above 3 } \\
\text { inflorescence }\end{array}$ \\
\hline Control & $18.07 \mathrm{a}$ & $4.48 \mathrm{a}$ & & $61.54 \mathrm{a}$ & $53.92 \mathrm{a}$ \\
Removing 1/3 & $14.51 \mathrm{ab}$ & $4.91 \mathrm{a}$ & & $63.21 \mathrm{a}$ & $56.69 \mathrm{a}$ \\
Removing 2/3 & $10.53 \mathrm{~b}$ & $6.49 \mathrm{a}$ & & $56.22 \mathrm{ab}$ & $51.76 \mathrm{a}$ \\
Removing all leaves & $5.92 \mathrm{c}$ & $5.92 \mathrm{a}$ & & $47.88 \mathrm{~b}$ & $47.88 \mathrm{a}$ \\
\hline CV $(\%)$ & 19.05 & 28.05 & & 12.43 & 15.74 \\
\hline
\end{tabular}

Means followed by the same letter in the column do not differ by the Tukey test at $5 \%$ (médias seguidas por pelo menos uma mesma letra na coluna não diferem entre si pelo teste de Tukey a $5 \%$ de probabilidade).

Table 2. Means of total and commercial production of tomato plants submitted to different levels of retreat of lower leaves (médias de produção total e comercial de tomateiro submetido a diferentes níveis de retirada de folhas baixeiras). Viçosa, UFV, 2009.

\begin{tabular}{lccccc}
\hline \multirow{2}{*}{ Treatment } & \multicolumn{2}{c}{ First experiment } & & \multicolumn{2}{c}{ Second experiment } \\
\cline { 2 - 4 } \cline { 5 - 6 } & $\begin{array}{c}\text { Total } \\
\text { yield }\end{array}$ & $\begin{array}{c}\text { Marketable } \\
\text { yield }\end{array}$ & & $\begin{array}{c}\text { Total } \\
\text { yield }\end{array}$ & $\begin{array}{c}\text { Marketable } \\
\text { yield }\end{array}$ \\
\cline { 2 - 5 } & \multicolumn{4}{c}{ (g/plant) } \\
\hline Control & $6131.43 \mathrm{a}$ & $3441.68 \mathrm{a}$ & $3990.21 \mathrm{a}$ & $3691.20 \mathrm{a}$ \\
Removing 1/3 & $7031.87 \mathrm{a}$ & $3929.73 \mathrm{a}$ & & $2964.02 \mathrm{~b}$ & $2607.19 \mathrm{~b}$ \\
Removing 2/3 & $6867.68 \mathrm{a}$ & $4018.37 \mathrm{a}$ & & $4221.46 \mathrm{a}$ & $3840.32 \mathrm{a}$ \\
Removing all leaves & $6431.09 \mathrm{a}$ & $4053.62 \mathrm{a}$ & & $4105.58 \mathrm{a}$ & $3693.90 \mathrm{a}$ \\
\hline CV(\%) & 16.42 & 24.51 & 19.11 & 19.94 \\
\hline
\end{tabular}

Means followed by the same letter in the column do not differ by the Tukey test at $5 \%$ (médias seguidas por pelo menos uma mesma letra na coluna não diferem entre si pelo teste de Tukey a $5 \%$ de probabilidade).

The data of the last assessment of damaged leaf area (\%) by diseases on the plants of the two experiments, both of the whole plant and also the damaged leaf area of the plants considered, only the leaves above the third inflorescence are shown in Table 1. The data suggested that, regardless of the experiment, removing all the basal leaves was efficient in reducing the damaged leaf area. Although this result cannot be generalized for all diseases, as for example late blight, whose symptoms occur initially on the upper half of the plant (Lopes \& Ávila, 2005), it indicated that this practice has potential for routine use to reduce leaf diseases of plants in the field.

The damaged leaf area of the plants above the third inflorescence was measured in order to show the fall in the quantity of inoculum that would by diseases because of the greater moisture from excessive rainfall that contributed to the increase in damaged leaf area above the third inflorescence of the plant.

The mean total production and commercial data for the plants are shown in Table 2. According to these data, removing the basal leaves did not interfere in the tomato yield. Removal of one or two leaves per sympodium hardly affected the division of dry matter among the vegetative organs and tomato fruit (Andriolo \& Falcão, 2000). According to these authors, the extra quantity of dry matter accumulated in the non-defoliated plants was not allocated to the fruit, but remained in the leaves. Furthermore, the remaining leaves on the plant came to have a greater photosynthesis rate (Wolk et al., 1983). According to Acock (1978), the upper third of tomato plants, although they have only $23 \%$ of the total leaf area of the plant, accounts for the interception of $73 \%$ of the total solar radiation and is responsible for $66 \%$ of the net photoassimilate production. Thus the basal leaves are not very important for the net photosynthesis of the plants and their contribution to photosynthesis decreased gradually as the tomato leaf age increased (Shishido et al., 1990).

In experiment 2 , the treatment removing one third of the basal leaves presented lower yield that was not due to leaf removal, because the treatments with higher leaf removal levels did not differ from the control. In this experiment, the treatments were distributed in sub-areas and in spite of the soil fertility correction by fertilizing, identical application of crop treatments and irrigation in the different subareas, other factors such as luminosity, wind, soil physical characteristics, temperature and moisture may have contributed to reducing the yield of the plants in this treatment.

No significant difference was observed in the analysis of variance for the fruit quality data in either experiment when the inflorescences of the plants were compared of the plants among the treatments. Thus basal leaf removal did not interfere in the fruit quality of any plants. 
Therefore removing all the basal leaves as the fruits were harvested was efficient in reducing the leaf area damaged by plant diseases, that might mean less severity and decreased inoculum in the cropping area. Thus this procedure has potential for being included as a routine practice during the management of this crop, to reduce disease severity and incidence.

It is emphasized that removing the basal leaves did not interfere in productivity and tomato fruit quality but studies on the adoption and efficiency of this practice in different planting periods, spacing, variety, successive crops and the efficiency in the control of specific diseases should be carried out. Furthermore, the financial viability of adopting this practice should be considered.

\section{REFERENCES}

ACOCK B; CHARLES-EDWARDS DA; FITTER DJ; HAND DW; LUDWIG LJ; WARREN WILSON J; WITHERS AC. 1978. The contribution of leaves from different levels within a tomato crop to canopy net photosynthesis: An experimental examination of two canopy models. Journal of Experimental Botany 29: 815-827.

AGRIANUAL. 2009. Anuário da Agricultura Brasileira. São Paulo: FNP Consultoria e Agroinformativos. p. 472-478.
ANDRIOLO JL; FALCÃO LL. 2000. Efeito da poda de folhas sobre a acumulação de matéria seca e sua repartição para os frutos do tomateiro cultivado em ambiente protegido. Revista Brasileira de Agrometeorologia 8: 75-83.

BARRETO M; SCALOPPI EG. 2000. Sistemas de previsão de doenças de hortaliças. In: ZAMBOLIM L (ed) Manejo integrado: doenças, pragas e plantas daninhas. Viçosa, MG, p. 169-186.

BLUME E; JARA ASA. 2004. Moléstias em tomateiro cultivado em estufas plásticas em quatro municípios da região central do Rio Grande do Sul, Brasil. Ciência Rural 34: 61-666.

BRASIL. 1995. Ministério da Agricultura do Abastecimento e da Reforma Agrária. Portaria $\mathrm{n}^{\circ} 553$ de 30 de setembro de 1995. Diário Oficial da República Federativa do Brasil. Brasília: Diário Oficial da União. Seção 1, p. 14464.

COMISSÃO DE FERTILIDADE DO SOLO DO ESTADO DE MINAS GERAIS. 1999. Recomendações para o uso de corretivos e fertilizantes em Minas Gerais. 5.ed. Lavras, 359p.

GOMES FP; GARCIA CH. 2002. Estatística aplicada a experimentos agronômicos e florestais. v.11. Piracicaba, FEALQ, 309p.

GUIMARÃES MA; CALIMAN FRB; SILVA DJH; MARIN BG; SOUZA JB. 2007. Tratos culturais em tomateiro. In: SILVA DJH; VALE FXR (eds). Tomate: Tecnologia de Produção. Viçosa, MG, p. 101-115.

LOPES CA; ÁVILA AC. 2005. Doenças do tomateiro. Brasília: Embrapa. Hortaliças. $151 \mathrm{p}$.

MIZUBUTI ESG. 2001. Requeima ou mela da batata e do tomate. In: LUZ EDN; SANTOS
AF; MATSUOKA K; BEZERRA JL (eds). Doenças causadas por Phytophthora no Brasil. Campinas-SP, p.100-174.

NAKANO O. 1999. As pragas das hortaliças: seu controle e o selo verde. Horticultura Brasileira 17: 04-05.

NUTTER JRFW. 1997. Disease severity assessment training. In: FRANCL LJ; NEHER DA (eds). Exercises in plant disease epidemiology. St. Paul, The American Phytopatological Society Press, p. 1-7.

SALUSTIANO ME; VALE FXRV; ZAMBOLIM L; FONTES PCR. 2006. O manejo da pintapreta do tomateiro em épocas de temperaturas baixas. Summa Phytopathologica 32: 353-359.

SAS INSTITUTE. 1989. Statistical user's guide, version 6 , fourth edition, volume 2 cary, $\mathrm{NC}$ : SAS Institute Inc. 846p.

SHISHIDO Y; CHEON JY; YUHASHI T; SEYAMA N; IMADA S. 1990. Changes in photosynthesis, translocation and distribution of ${ }^{14} \mathrm{C}$-assimilates during leaf development and the rate of contribution of each leaf to fruit growth in tomato. Journal Japanese Society Horticultural Science 59: 771-779.

VALE FXR; JESUS JR WCJ.; RODRIGUES FA; COSTA H; SOUZA CA. 2007. Manejo de doenças fúngicas em tomateiro. In: SILVA DJH; VALE FXR.(eds). Tomate: Tecnologia de Produção. Viçosa-MG, p.159-197.

VALE FXR; ZAMBOLIM L; PAUL PA; COSTA H. 2000. Doenças causadas por fungos em tomate. In: ZAMBOLIM L; VALE FXR; COSTA H. (eds). Controle de Doenças de Plantas: Hortaliças. Viçosa-MG, UFV, p.699-756.

WOLK JO; KRETCHMAN DW; ORTEGA JUNIOR DG. 1983. Response of tomato to defoliation. Journal of American Society for Horticultural Science 108: 536-540. 